DOI: 10.21802/gmj.2020.2.6

\title{
Review
}

\section{Abdominal Sepsis. Some Genetic-Molecular Mechanisms of Its Occurrence}

Vasyl Kavyn

\begin{abstract}
Sepsis is a dangerous pathology which is characterized by a high mortality and morbidity in the whole world. Among varieties of sepsis an abdominal sepsis takes the second position. A huge number of scientific investigations, dedicated to sepsis, were done and are being done now. The search for new pathophysiological links of sepsis is ongoing. Studies show that more and more scientists pay attention to the status of genes polymorphism and their influence on the molecular mechanisms of the course of abdominal sepsis, which can help to decide this complex medical problem.
\end{abstract}

Keywords

abdominal sepsis; gene polymorphism; endotoxin; cytokin; inteleukin; trace elements

Ivano-Frankivsk National Medical University, Ukraine

Corresponding author: kavynv@ukr.net

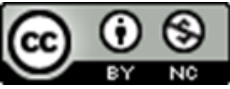

Copyright @ (Vasyl Kavyn, 2020

Even in economically developed countries, sepsis is characterized by a lack of tendency to a decrease of the number of patients and high mortality, despite the modern arsenal of diagnostic measures, the newest methods of treatment, the use of strong antibacterial agents and considerable funding. Sepsis remains a pressing problem in medicine. For example, about 75000 cases of severe sepsis or septic shock are diagnosed annually by physicians in Germany [1]. In the United States, particularly in 2009, 1.6 million patients were treated for septicaemia. Budgetary costs for the treatment of septicemia were $\$ 20.3$ billion in 2011, in the US. Sepsis, according to a financial cost of its treatment, is among the top of ten nosologies [2]. In addition, patients who had sepsis, require long-term rehabilitation due to susceptibility to many diseases and they are in a group of risk of mortality in the next 5 years.

For the past 5 years, there has been an increase in mortality rates in patients with a surgical pro- file with severe infectious complications, and this trend promises to be stable [35]. According to frequency of detection, abdominal surgical infection ranks the second position after respiratory tract infections [73]. Abdominal sepsis mortality remains high in $30 \%$, and infectious- toxic shock mortality rises to $80 \%$ [68].

In Ukraine, official data concerning sepsis and mortality data are controversial and inaccessible [2]. One of the reasons the high sepsis mortality rate in Ukraine is the lack of verified sepsis cases, which makes it impossible to objectively assess the magnitude of the problem and apply adequate tactical and management decisions. Formation regional or national registers of sepsis will help to investigate the epidemiological, clinical, microbiological and profile regimen of treatment of patients with sepsis. This can effect on decrease of a mortality and improve the global situation with sepsis as a whole [33].

Sepsis classification according to Bone: bac- 
teriemia, systemic inflammatory response syndrome, sepsis, severe sepsis, septic shock, multiple organ failure syndrome [46]. There are main modern theories of sepsis: the theory of hyper-inflammation, the theory of immunosuppression, the theory of twophase response, the theory of "chaos", the theory of "non-bacterial sepsis" and the theory of immune imbalance [50]. Among main mechanisms of development and progress of sepsis there are infectioustoxic, microcirculatory and mediator ones. Mainly, all mechanisms are simultaneously involved in the development of sepsis [29, 30]. There are four phases of sepsis: induction, cascade, secondary autoaggression phase and multiorgan dysfunction phase. Among the main criteria that indicate the occurrence of sepsis there are: focus of infection with systemic inflammatory response syndrome and bacteriemia; prolonged fever; bacteriemia; multiple appearance of purulent focuses or recurrence of the disease.

The interaction of the macroorganism and the infectious agent causes a controlled local inflammatory reaction. The inflammatory response on a bacterial infection begins with the recognition of a pathogen-associated bacterial substance. A significant role in the body's susceptibility to sepsis belongs to its genetic map [4], which influences the pathophysiological links of sepsis [6]. Initial recognition and the resultant response are supported by a large number of cellular proteins, which in most cases are polymorphic. Non-histone amphoterin protein (HMGB1), which is increased in sepsis, affects gene transcription and nucleosome formation [50]. Amphoterin can bind with NFkappaBdependent signaling receptors, expressed on myeloid and lymphoid cells: toll-like receptors (TLR2, TLR4, TLR9), glycosylation end-receptor (RAGE) and myeloid cell-triggered receptor (TREM-1). Interaction with these receptors causes pro-inflammatory activation of myeloid cells and leads to the formation of pro-inflammatory mediators, which is the cause of systemic inflammatory process [52]. Variations in genes that encode proteins may determine the general response of organism to infection. Polymorphic variants of genes determine the individual features of metabolic processes at the cellular level, determining the individuality of reactions on the action of exogenous factors and endogenous products that are formed under oxidative stress. Mainly, from 2 to 9 associations of microorganisms cause the development of abdominal sepsis. Among pathogenic agents of abdominal sepsis there are representatives of Enterobacteriaceae: E. coli, Proteus, Klebsiella, Enterobacter, Serratia, E. cloacae, K. pneumonia, P. aeruginosa, S. aureus, E. faecalis $[19,20]$. In experimental abdominal sepsis, E. coli and bacteria of the Bacteroides were mainly detected. It was characteristic that the species composition of the autofeces and the species composition of microorganisms which were detected in the abdominal cavity differed after the autofeces insertion into the abdominal cavity. There were no bifidobacteria, peptococci, peptostreptococci. Clostridial forms of bacteria are not often detected. In statistically significant concentrations, fungi of the Candida kinds were found in the abdominal cavity of experimental rats, whereas in autofeces these fungi were detected in some cases [24]. Fungi of the Candida family have pathogen factors among which there are an adhesion, that is an ability fixing to the cells of the host (epitheliocytes, endothelial cells, etc.), the presence of proteinases and lytic enzymes which take a part in phospholipolysis; ability a transforming into a hyphal form, that enhances the adhesive properties of fungi of Candida kinds; suppressive effect on T-dependent immune responses that are associated with the presence of mannan in the cell wall and phenotype changes of fungi of Candida kinds, which causes their considerable variability, resistance to mutations and adverse factors [24]. Role of other microorganisms is minor, as the study shows. These microorganisms are associated with Escherichia and bacteroides [22]. Beside, these microorganisms enhance the virulence of the primary pathogen and suppress factors, mechanisms of nonspecific and specific immunity [23]. However, it is not always possible to carry out bacteriological verification (the presence of microflora is determined only in $45-70 \%$ of cases in sepsis), which may be explained by imperfect bacteriological examination and that dead and damaged tissues cause a generalized inflammatory response [25]. The use of mod- 
ern molecular methods (polymerase chain reaction, fluorescence in situ hybridization - FISH) that allow to detect pathogens in $80-100 \%$ are expensive, sensitive to contamination and require the appropriate qualification of laboratory workers [57]. Products of vital activity of microorganisms, their endo- and exotoxins, end products of metabolism, the concentration of which exceeds the norm (lactate, ammonia, urea, creatinine, etc.), components of cellular, tissue, organ regulatory systems in high concentrations (circulating immunocomplexes, peroxidation products, biogenic amines, etc.), membrane enzymes (trypsin, amylase, hydrolases), toxic substances (indole, scatol) lead to the development of endogenous intoxication. Gram-negative microorganisms produce endotoxin that can be detected in serum by the LAL- test [46], and gram-positive microorganisms "undress" components of their membrane (peptidoglycan, lipoic acid, etc.) [38]. Others factors of virulence of microflora affect the development of sepsis. For example, enterococcus cytolysin causes erythrocyte hemolysis; aggregation substance has a cytotoxic effect on the heart and lungs; microorganisms' gelatinase helps to penetrate the basilar membrane; extracellular superoxide activates lipid peroxidation and lymphocyte apoptosis [48]. Endotoxin is one of the strongest exogenous modulators of immunological reactivity. The biological activity of endotoxin depends on the lipid component (lipid A) [45, 46]. Under the influence of a lipopolysaccharide the cells of the myelomonocytic series, Kupffer cells of the liver [48] produce endogenous inflammatory mediators [45]. At the study of electron microscopic criterions of the functional activity of mononuclear macrophages, two populations of mononuclear macrophages with increased and decreased functional activity were identified in the inflammation site. The presence of mitochondria with increased matrix density and tightly packed cristae indicates on expressed their functional activity. Some mitochondria contain a homogenized matrix. In one group of mitochondria it is found accumulation of microchannels, cytolysosomes, in other group mitochondria it is found tubular structures and dense granular material and these mitochondria similar on residual corpuscles cov- ered by a single membrane. The presence of secondary lysosomes and microorganisms indicates strong phagocytic activity [43]. Like pathogenic microorganisms, the remnants of destroyed mitochondria cause an inflammatory reaction also. It confirms the bacterial origin of the mitochondria. In mitochondria, as in bacteria, the nuclear genome DNA sections are not methylated [59].

Endotoxin, entering into the blood, leads to the whole complex cascade of pathological changes in the body at intra-abdominal infection [19]. Endotoxin is able to activate endotoxin-binding protein of plasma, leading to stimulation of CD14 receptor structures on cells of the monocyte-macrophage system, that is, the so-called pattern receptors. In this processing a splitting off from the CD-14 monocyte /macrophage receptor complex and the formation of presepsin is carried out [59]. Presepsin is used as a biomarker of infectious sepsis [32]. There are pattern recognition receptors: Toll (TLRs) -like receptors, NOD (NLRs) -like receptors and RIG (RLNs) -like receptors. Toll-like receptors and NOD-like receptors are the most important components of innate immunity that protect the organism against infection. However, there are possible disorders and changes in Toll-like receptors, in signal transduction from receptors, gene polymorphism that only escalate and complicate the course of sepsis. For example, the presence of a mutation in the gene encoding IRAK-4 kinase causes severe purulent processes [61]. Toll-like receptors recognize the major molecular patterns of bacteria, viruses, fungi and other pathogens [39]. Under the influence of Toll-like receptors, transcription and induction of genes are initiated, which initiates general mechanisms of immune defence $[58,60]$. Kinin, coagulation, complement, peripheral blood cells - neutrophils, eosinophils, monocytes, macrophages, endothelial cells are activated. This causes the enhancing the synthesis of pro-inflammatory cytokines (interleukin $-1,-6,-8,-12)$, TNF- $\alpha$ and TNF- $\beta$, CCL2, CCL5, CCL11 chemokines, and increase the number of anti-inflammatory mediators (interleukin -4, $-10,-13)$, leading to a systemic inflammatory response syndrome [36, 39]. Cytokines have a wide range of biological effects, that is manifested by 
changes in metabolism, hematopoiesis, vascular properties, functions of regulatory systems, such as the central nervous system [46]. Cytokine activity is genetically determined [47]. For example, when studying the polymorphism of the gene responsible for the synthesis of TNF- $\alpha$, it was found that the presence of a mutated allele in it is associated with the progression of sepsis [55]. At abdominal sepsis, the most often gene variant CC is detected, rarely the CT and TT gene variant is detected. It is indicated an unfavourable course of sepsis with the CT and TT variant of the gene [18]. Cytokine formation is caused by the activation of nuclear factor (NK-kB) [50]. Monocyte-macrophage cytokines predominate in the early sepsis phase, whereas in the late sepsis phase lymphocyte-derived cytokines and the interferon dominate. Aggravation of sepsis and development of septic shock are associated with loss of regulatory activity of lymphocytic cytokines [44]. Studies show that interleukin-6 level increase depending on the severity of abdominal sepsis. Its value can be up to five times higher than the control value that is associated with interleukin6 gene polymorphism [47]. Interleukin-8 is proinflammatory. In conditions of abdominal sepsis, the interleukin-8 is increased, and with the development of multiple organ failure, its content is decreased. Interleukin-1 (anti-inflammatory receptor antagonist) increases with the severity of abdominal sepsis and its content remains high at multiple organ failure [37]. Interleukin-10 also increases at abdominal sepsis. It is known, interleukin-10 inhibits Tcell proliferative activity and inhibits monocyte activation. Interleukin-17 stimulates pro-inflammatory responses at sepsis and promotes formation of interleukin-1 $\beta$, interleukin-6, TNF- $\alpha$ [51]. TNF- $\alpha$ is one of the important cytokines that is synthesized by immune cells and adipocytes. This cytokine stimulates the secretion others cytokines by endothelial cells and leukocytes. TNF- $\alpha$ affects the metabolism of arachidonic acid and causes cell apoptosis [62]. Damage endothelial cells, lipopolysaccharide of microorganisms leads to a decrease the level of angiotensin-converting enzyme [47], which contributes the catalysis of angiotensin II synthesis. Angiotensin II is a pro-inflammatory mediator, which regulates the production of cytokines, in particular, interleukin-6. Synthesis of angiotensin-enzyme is activated by macrophages and T-lymphocytes. The DD genotype of the angiotensin-converting enzyme is associated with the development of sepsis [47]. It was found an increase of Endo-Cab sign, depending on the severity of the course of abdominal sepsis. However, analysing the results of changes of cytokines, significant individual variations of these indicators were revealed that indicates the expedience of their study in the dynamics of the course of abdominal sepsis [26]. Imbalance of cytokines characterizes the influence of cytokine dysregulation on the pathogenesis of severe sepsis, but not general level of hypercytokinemia [3]. Correlation of IL-1$\mathrm{Ra} / \mathrm{TNF}-\alpha$ and IL-10/IFN- $\gamma$ characterizes cytokine dysregulation and severity of sepsis. Low levels of interleukin- 2 and IFN- $\gamma$ evidences about cytokine dysregulation [49]. Suppression of interleukin-2 production at low proliferative activity of mononuclear cells is a reliable sign of T-cell energy. T-cell energy, along with reduced proliferative response, indicates the severity of sepsis. Research shows that the autonomic nervous system affects the immune system, leading to inhibition of cytokine synthesis. Under the influence of acetylcholine, macrophages reduce the synthesis of proinflammatory cytokines [50], while under the influence of catecholamines, the content of pro-inflammatory cytokines increases, lymphocyte activation occurs, cell proliferation and apoptosis are stimulated [50].

Endotoxicosis and increased levels of pro-inflammatory cytokines induce procalcitonin production [32]. Procalcitonin is produced in the liver, kidneys, muscles and other parenchymal cells at inflammation. It has been noted that procalcitonin can act as a modulator of the inflammatory-immune response [28] and at the same time procalcitonin can cause toxic effects on the tissues [28]. Procalcitonin is used as a biomarker of sepsis [34]. However, procalcitonin does not reflect the severity of sepsis [32]. In the case, when regulatory systems fail to maintain homeostasis, the destructive effects of cytokines and other mediators begin to dominate, 
that leads a disorder capillary endothelial permeability and its function [39]. Disorder of the balance between pro-inflammatory and anti-inflammatory factors causes autoagression and hypercatabolism.

Damage of the vascular endothelium arises in a result of the activation of blood coagulation, complement systems, blood cells, including macrophages and neutrophils under the influence of microbial cells [46]. The complement system is represented by the protein complex which affects the course of sepsis the course of sepsis. In particular, increasing a content of C5a can lead to an imbalance in the coagulation system, immune paralysis or multiple organ failure [50]. Studies show that the content of erythrocytes and hemoglobin at sepsis is reduced, which is caused by hemolysis and apoptosis of erythrocytes and it is one of the causes of anemia of varying severity [42]. At abdominal sepsis, the sorption capacity of erythrocytes increases [11]. Microbial endotoxins cause hemolysis of red blood cells. Erythrocyte apoptosis is caused by some components of blood plasma that have not yet been identified [8]. The heme that is released in a result of hemolysis and apoptosis is toxic and a role of heme is important at oxidative stress, injuring a tissues and cells of the immune system [9]. The products of its oxidation adversely affect the migration of neutrophils to the pathological focus [10]. Activation of neutrophils and platelets is manifested by an increase of their adhesive properties, degranulation and release of oxygen radicals and proteases. Macrophage activation is accompanied by the release of not only cytokines, but also platelet activation factors, colonies of stimulating factors, metabolites of the arachidonic acid cycle, thromboxanes, prostaglandins, leukotrienes, activation of T-lymphocytes with the release of interleukin-2, gamma interferon [46]. Macrophages are activated by the inhibition factor of migration, the secretion of which is caused by exotoxins, endotoxins and pro-inflammatory cytokines [50]. The total number of T-lymphocytes decreases almost twice, the content of T-helper cells that stimulate the immune response in abdominal sepsis decreases, but the relative number of T-suppressors increases [12] or remains unchanged [26]. With the increase of en- dotoxemia, the content of T-lymphocytes CD3, Thelper CD4 and immunoregulatory index CD4/CD8 are decreased. The content of circulating immune complexes increases 1.5-fold in abdominal sepsis. Decrease of immunoregulatory index and an increase of circulating immune complexes evidence about immunological imbalance that plays an important role in the pathogenesis of abdominal sepsis [26]. Correlation of T/B lymphocytes decreases and CD19+ increases twice that indicates on dysregulation in the immune system [26]. Evaluating humoral immunity under conditions of severe endotoxemia, a decrease of the content of $\operatorname{IgM}, \mathrm{IgG}$, IgA is revealed. Immunoglobulins $\mathrm{M}$ and $\mathrm{A}$ belong to the acute phase immunoglobulins. These immunoglobulins have insufficient specificity for antigens and effective completion of inflammation, but in insufficient IgG levels an IgA, IgM can partially assume its functions. Lymphocytes with the marker CD22 in conditions of endotoxemia are significantly reduced [16]. The content of neutrophilic granulocytes with degenerative changes increases at abdominal sepsis exudate, the number of macrophages increase and the content of interleukin-6 is high [31].

Microbial endotoxin and pro-inflammatory cytokines induce secretion of tissue factors, which potentiate the processes of coagulation from endothelial cells and monocytes that leads to excess coagulation processes. The activity of natural anticoagulants such as heparin, antithrombin, protein $\mathrm{C}$, thrombomodulin in sepsis is reduced, and an imbalance of anticoagulant mechanisms can lead to a bleeding or thrombosis [53]. It appears the so-called "loop gain" - inflammation increases coagulation and excessive coagulation increases inflammation. This leads to vascular collapse that is the cause of the appearance of the microcirculatory bed thrombosis and activation of hypoxic and free radical necrobiosis in tissues injured by ischemia that leads to micro-vessel disorders and multiple organ failure [39, 41]. In sepsis, excessive activation of coagulation can be caused by neutrophil extracellular traps. Neutrophils release neutrophil extracellular traps which contain nucleic acids, histones, and granule contents (myeloperoxidase, neutrophil elastase). Neutrophil extracellular traps form web- 
like formations that trap pathogens, reducing their spread and improvement of neutrophil antimicrobial activity [68]. However, neutrophil extracellular traps that cause an excessive coagulation might lead to disseminated intravascular coagulation $[69,70]$. Microcirculatory lesions, arising in a result of sepsis, are associated with the excretion of atomic oxygen, lytic enzymes, vasoactive substances (NO) and endothelial cell growth factors $[39,40]$. Increase concentration of nitric oxide (NO) in sepsis is associated with stimulation of macrophages by TNF- $\alpha$, interleukin-1 and synthesis of nitric oxide by vascular endothelium. The formation of nitric oxide is regulated by the enzyme NO-synthase. In sepsis an increase of nitric oxide is able to enhance the self-destructive action of cytokines and endotoxins, which can lead to a septic shock [50]. Besides, nitric oxide is involved in antimicrobial protection, causing the death of microorganisms or adversely affects on their reproduction and growth. The antimicrobial action of nitric oxide is carried out through the processes of nitrosylation and deamination of proteins, oxidative damage and disorder of DNA reparation [66]. Nitric oxide causes hemodynamic instability, which results in the relaxation of vascular smooth muscle and leads to hypotension [39]. Nitric oxide forms a complex with heme ferrous cytochrome P450 and inactivates this enzyme of monooxygenase system, which has the ability to catalyze oxidation reactions, to take a part in oxidative, peroxidase metabolism of endogenous substances (steroids, bile acids, leukotrienes, etc.), activated at appearance of foreign substances [14]. In the overproduction of nitric oxide in the conditions of intensification of the processes of free radical oxidation, a highly active compound of peroxynitrite is formed. It has high reaction activity. Peroxynitrite takes a part in the nitration of tyrosine remnant in proteins, destroys membrane lipids, damages the endothelium [21], initiates lipid peroxidation, inactivates aconitase, inhibits electron transport in mitochondria, oxidizes biological thiols. Peroxynitrite is a strong DNA-destroying agent [22], which initiates the processes of apoptosis. Metabolized peroxynitrite is capable to cause destruction of almost all cell components. Complex
S-nitrosoglutathion is formed as a result of connection of glutathione with nitric oxide. That complex S-nitrosoglutathion is a depot of endogenous nitric oxide (NO release is catalyzed by the thioredoxin system). This increases the bioavailability of this molecule, prevents its binding with superoxide anion and the formation of peroxynitrite [17].

Disorders of microcirculation in sepsis lead to tissue hypoxia, the predominance of anaerobic glycolysis and the accumulation of active forms of oxygen (superoxide radical $\left(\mathrm{O}_{2}\right)$, hydrogen peroxide $\left(\mathrm{H}_{2} \mathrm{O}_{2}\right)$, hydroxyl radical $(\mathrm{OH})$, peroxynitrite, hypochlorite) [55]. Tissue hypoxia and anaerobic glycolysis in sepsis lead to lactic acidosis. In addition, in sepsis glucose entry into cells was impaired, leading to hydrocarbon hypermetabolism, which is also a prerequisite for the occurrence of lactic acidosis [63]. According to studies, the content of lactate correlates with the severity of sepsis. Determination of lactate content in sepsis is more accurate in capillary blood than in arterial or venous blood [64]. With the development of sepsis, the content of toxic lipoperoxidation products, including diene conjugates and malondialdehyde increases that is caused by the processes of free radical oxidation.

In sepsis endothelial dysfunction is characterized by an imbalance between the substances produced by the endothelium. The main markers of endothelial functional status include nitric oxide, endothelin-1 (Et-1), Willebrand factor, changed endothelial cells [55]. Endothelin -1 is a nitric oxide antagonist and has the properties of a strong vasoconstrictor. Role endothelin-1 has not yet been fully studied at inflammatory processes. The Willebrand factor is synthesized by endothelial cells at vascular damage and provides the binding of platelet receptors with subendothelial structures of the damaged vessel [55]. In abdominal sepsis, fluid is released from the vascular bed to the interstitium. The course of inflammation process depends on number of mediators involved in this, affecting the vascular endothelial permeability, causing to the greater loss of fluid that is manifested by the development of capillary leak syndrome [13]. The occurrence of capillary leak syndrome is associated with disorder vascular endothelial function [52] that can be 
damaged by prostaglandins and thromboxane [51].

Gene polymorphism may influence metallothionein 2 expression. Metallothionein 2 is a cysteinerich low-weight protein found in the body. Its main function is binding, transfer and organ accumulation of metals [76]. A trace elements and metal enzymes effect interaction of micro-and macroorganism in sepsis [7]. Trace elements and metal enzymes effect hematopoiesis, processes of tissue respiration, energy metabolism, immunological reactions, synthesis of biologically active substances, predetermine the level of free radical processes in tissues and organs. Studies show that the content of iron [75], copper and zinc in whole blood with increasing endotoxemia, is significantly reduced [15]. Some gram-positive and gram-negative bacteria which can produce siderophores need in iron acquisition [74]. According data [70, 71], zinc accumulates in metabolically and immunologically active organs such as the liver and spleen at sepsis. Biogenic trace elements cobalt and zinc can effect lipid peroxidation activity and antioxidant protection system. The copper-containing enzyme ceruloplasmin is synthesized in the liver and lungs and provides transport of copper to form cytochrome C oxidase, zinc-dependent superoxide dismutase. Ceruloplasmin is able to inhibit lipid peroxidation and influence the course of the inflammatory process [56]. Selenium deficiency in the organism impairs the course of sepsis and affects the content of CD14 lymphocytes. The decrease the activity of seleniumcontaining glutathione peroxidase causes a decrease the bactericidal properties of neutrophils [65]. Manganese is one of the vital elements of the body. Basically manganese is present in mitochondria. It is found that manganese prevents lipid peroxidation [65] which is increased in sepsis. There are $\mathrm{Fe}-, \mathrm{Cu}-, \mathrm{Zn}-, \mathrm{Mn}$ - dependent superoxide dismutase depending on the trace element which takes part in the formation of superoxide dismutase [57]. Studies show that superoxide dismutase content decreases almost twice in sepsis.

\section{Conclusions}

Thus, problem of abdominal sepsis remains topical and undecided nowadays. Studied different pathological links have not answered the high data of mortality and morbidity in abdominal sepsis. Further study of molecular mechanisms of sepsis course in combination with gene polymorphism will help to understand appearance complications and mortality in abdominal sepsis.

\section{Conflict of Interest}

The author stated no conflict of interest.

\section{Financial Disclosure}

The author declared no financial support.

\section{References}

[1] Moerer O, Quintel M. Sepsis in adult patients - definitions, epidemiology and economic aspects. Internist (Berl). 2009; 50 (7): 788, 790-4, 796-8. DOI: https://doi. org/10.1007/s00108-008-2285-7

[PMid:19436977]

[2] Nesterenko AN. Sovmestny proekt The Survivin Sepsis Compain, The Eoropean Society of Intensive Care Medicine \& The Society of Critical Care Medicine. Shpytalna hyrurgiia. 2016; 1: 6-7.

[3] Kozlov VK. Sepsis: etiologiia, immunogenez, konceptciia sovremenoy imunoterapii. Kyiv: ANNA-T; 2007. 296s.

[4] Pohilko VI. Rol genetychnoi determinanty v rozvytku krytychnyh staniv u ditey. Svit medycyny ta biologii. 2011; 2: 178-184.

[5] Salnikova LE, Smelaya TV, Moroz VV. i dr. Geny detoxikatcii xenobiotykov $i$ ih rol v razvitii pnevmonii. Obsthaya reanimatologiya.2008; $6(4): 9-15$.

[6] Nesterenko AN. Apoptoz tcirkuliruyustchih neytrofilov pri khirurgicheskom sepsise: 
patogeneticheskoe znachenie i prognosticheskie vozmozhosti. Ukrainsky zhurnal khirurgii.2010; 1: 122-131.

[7] Klymenko YuA, Klymenko AO, Shevchuk IM. Znachennya porushennya metal- metalofermentnoho gomeostazu v intesyfikatcii bakterialnoi agresii u hvoryh $\mathrm{z}$ gostrym zagalnym perytonitom. Ukrainsky zhurnal khirurgii.2011; 4: 173-176.

[8] Daniela K, Akel Ah, Lang Ph, et al. Suicidal erythrocyte death in sepsis. J Mol Med. 2007; 85 (3): 273-281. DOI: https://doi. org/10.1007/s00109-006-0123-8 [PMid:17180345]

[9] Larsen R, Gozzelino R, Jenney V, et al. Central Role for free Heme in the pathogenesis of severe sepsis. Sci Trans Med.2010; 2 (51): 51-71. DOI: https://doi.org/ $10.1126 /$ scitranslmed. 3001118 [PMid:20881280]

[10] Freitas A, Alves-Filho JC, Trevelin SC, Spiller F. Divergent Role of Heme Oxygenase inhibition in the pathogenesis of severe sepsis. Shock. 2011 [Epub ahead of print] DOI: https://doi.org/10.1097/SHK. 0b013e31820e1efo [PMid:21330952]

[11] Benedykt VV. Abdominalny sepsis u hvoryh na gostry perytonit. Shpytalna khirurgiya.2013; 3: 70-73.

[12] Deykalo IM, Mahnitcky IM, Sokolyk MB. Imunokorektciya $\mathrm{v}$ komplexnomu likuvanni hvoryh na gostry abdominalny sepsis. Shpytalna khirurgiya.2010; 3: 27-30.

[13] Kursov SV. Zvyazok mizh indexom leykotcytarnoyi intoxykatcii indeksom ta proyavamy syndromu kapilyarnoho vytoku u hvoryh na abdominalny sepsis. Kharkivska khirurgichna shkola.2013; 1: 57-62.

[14] Krivoruchko IA, Zhukov IA, Ivanova YuV, Pavelichenko MS, Moiseinko AS. Korrektciya narusheniy mikrosomalnoho okisleniya pecheni pri ishemii-reperfuzii tonkoy kishki u krys. Kharkivska khirurgichna shkola.2013; 1: 34-37.

[15] Skrypko VD, Klymenko AO, Gonchar MG, Klymenko YuA, Shevyak PI. Znachennya porushennya mikroelementnoho gomeostazu v patogenezi formuvannya endotoxykozu pry hostry kyshkovy neprohydnosti. Arhiv klinichnoyi medycyny.2014; 2: 118-120.

[16] Churpy IK, Pyptyuk OV, Yakubovska IO, Churpy KL, Churpy VK. Zminy gumoralnoyi ta klitynnyh lanok imunitetuu u hvoryh na rizni formy perytonitu. Arhiv klinichnoyi medycyny.2014; 2: 139-141.

[17] Mamchur DV, Desyateryk VI, Zhyluk VI, Levih AE, Abramov AV. Vyznachennya vplyvu L-lizynu estcynatu ta glutarginu na systemu oxydu azotu ta morfometrychnu harakterystyku endoteliotcytiv pechinky stchuriv z mechanichnoyu zhovtyanytceyu. Kharkivska khirurchna shkola.2017; 2: 7-11.

[18] Polyansky IYu, Moroz PV. Vybir likuvalnoyii taktyky pry riznyh formah gostroho perytonitu zalezhno vid genetychno determinovanyh porushen imunologichnoyi reaktyvnosti. Arhiv klinichnoyii medycyny.2014; 2: 96-98.

[19] Fomin PD, Sydorchuk RI. Abdominalny sepsis (ohlyad literatury). Suchasni medychni tehnologii.2009; 4: 60-67.

[20] Bodyaka VYu, Ivatchuk OI, Beh VV. Vplyv vnutrishnyocherevnoyi gipertenzii na osoblyvosti bakterialnoyi translokatcii za umovy modelyuvannya ta khirurhichnoho likuvannya hostroho poshyrenoho perytonitu. Klinichna ta eksperementalna patologiya.2011; 4: 7-17.

[21] Buryak OG. Monooxud nitrogenuprognostychna tcinnist $u$ diagnostytci dyhalnoho dystresu legenevoho genezu v novonarodzhenyh na tli dotatcy vysokyh kontcentratcy kysnyu. Klinichna ta eksperementalna patologiya.2011; 4: 1-23. 
[22] Kulmatytcky AV, Shevaha VM, Bilobryn MS. Oxyd azotu ta perekysne okyslennya lipidiv $\mathrm{u}$ hostromu periodi povtornoho ishemichnoho insultu. Klinichna ta eksperementalna patologiya.2011; 4: 49-56.

[23] Polyovy VP, Sydorchuk RI, Palanytca AS, Myshkovsky YuM. Vydovy sklad ta populyatciyny riven mikroflory hrobakopodibnoho vidrostka hvoryh na abdominalny sepsys unslidok destruktyvnoho apendytcytu. Klinichna ta eksperementalna patologiya.2011; 4: 182.

[24] Holubka OV, Savinova EM, Loshko GA, Zhuravlyova IV. Faktory patogennosty grybov roda Candida. Klinichna ta eksperementalna patologiya.2011; 4: 182.

[25] Kuznetcov AA. Sovremennaya diagnostika khirurhicheskoho sepsisa. Suchasni medychni tehnologii.2010; 1: 59-62.

[26] Desyateryk VI, Shapovalyuk VV, Kosynsky OV, Krykun MS. Immuny dysbalans $\mathrm{u}$ patogenezi abdominalnoho sepsysu pry destruktyvnomu pankreatyti. Shpytalna khyrurhiya.2016; 1: 38-42.

[27] Budkevich LI, Lekmanov AU, Soshkina VV. Rol prokaltcytoninovoho testa $\mathrm{v}$ ranney diagnostike sepsisa u detey s obshyrnymi ozhogami. Rossiyskiy vestnik penatologii i pediatrii.2001; 6: 107-113.

[28] Davis KA, Santaniello JM, He LK, et al. Burn injury and pulmonary sepsis: development of a clinically relevant model. J Trauma.2004; 2: 272-278. DOI: https: / / doi .org/10. 1097/01.TA.0000108995.64133.90 [PMid:14960967]

[29] Chong DL, Sriskandan S. Pro-inflammatory mechanisms in sepsis. Contrib.Microbiol.2011; 17: 86-107. DOI: https://doi .org/10 . 1159/000324022 [PMid:21659748]

[30] Esmon CN, Xu J, Lupu F. Innate immunity and coagulation. Tromb.Haemost.2011; 9
(1): 182-8. DOI: https://doi.org/10 . 1111/j.1538-7836.2011.04323.x

[PMid:21781254 PMCid:PMC3151110]

[31] Veliev NA, Gasanova DN, Ismailov VF. Vzaimnaya rol faktorov endotoxikoza i sindroma vnutribryushnoy gipertenzii v patogeneze abdominalnoho sepsisa Klinichna khirurgiya.2013; 10: 21-23.

[32] Velkov VV. Presepsyn- novy vysokoeffektivny biomarker sepsisa. Laboratorna diagnostyka.2012; 3: 64-70.

[33] Gerych ID, Dzyubanovsky IYa, Rusyn VV, ta inshi. Prospektyvne observatciyne bagatocentrove doslidzennya: Zahidno-ukrainskyi reestr sepsysu. Shpytalna hirurhiya.2013; 2: 103-104.

[34] Maltceva LA, Mosentcev NF, Kutuvoy AB, i drugie. Sepsis: diagnoz, antimikrobnaya terapiya s pozitcyi novyh mezhdunarodnyh rekomendatcy. Shpytalna hirurgiya.2013; 2: 105-106.

[35] Stetc MM, Harchenko LO, Galyga TM. Osoblyvosti diagnostyky ta kompleksne likuvannya hvoryh iz khirurhichnym sepsysom. Shpytalna khirurhiya.2013; 2: 107-108.

[36] Starosek VN, Puzako VV, Butyrsky AG, i drugie. Immunoterapiya rasprostrannenoho peritonita kak prophilaktica abdominalnoho sepsisa. Shpytalna khirurhiya.2013; 2: 109110.

[37] Grebenyuk VV, Yusan NV. Rol interleykina 8 i retceptornoho antagonista interleykina $1 \mathrm{v}$ patogeneze abdominalnoho sepsisa. Immunolohiya.2010; 1: 45-46.

[38] Grinchenko SV. Suchasni pidhody antybakterialnoho likuvannya hvoryh z gostrym sepsysom. Kharkivska khirurguchna shkola.2013; 6: 3941.

[39] Desyateryk VI, Shapovalyuk VV, Shevchenko ES. Suchasni pidhody do diagnostyky ta 
likuvannya sepsysu. Kharkivska khirurhichna shkola.2014; 1: 45-51.

[40] Saha R, Das S, Chatterjee R, et al. The pathophysiology of septic shock. International journal of pharma and Bio Sciences.2010; 1 (2): $1-1$.

[41] Opal S. The current understanding of sepsis and research priorities for the future. Virulence.2014; 5 (1): 1-3. DOI: https: //doi.org/10.4161/viru.26803 [PMid:24153016 PMCid:PMC3916364]

[42] Dronyak MM. Osoblyvosti likuvannya hvoryh z pryvodu pislyaoperatciynoho perytonitu, uskladnenoho abdominalnoho sepsysom. Klinichna khirurhiya.2012; 5: 36-39.

[43] Homyak IV. Ultrastrukturni osoblyvosti mononuklearnyh makrofahiv demarkatciynoi zony pry hostromu necrotychnomu pankreatyti ta rozrobka sposobiv prognozuvannya perebigu zahvoryuvannya i yuho likuvannya. Klinichna khirurgiya.2012; 5: 27-31.

[44] Hotchkiss RS, Karl IE. The pathophysiology and treatment of sepsis. N.Engl.J.Med.2003; 348: 138-150. DOI: https://doi. org/10.1056/NEJMra021333

[PMid:12519925]

[45] Prytulo LF. Vliyanie patogeneticheskoy immunokorektcii na soderzhanue provospalitelnyh mediatorov i tcytokinov T-helperov 1, 2 tipov $\mathrm{u}$ detey $\mathrm{s}$ sindromom sistemnoho vospalitelnoho otveta, vyzvannoho gramotritcatelnoy infektcyi. Khirurgiya dytyachoho viku.2009; 3: 40-43.

[46] Kedyk LV. Taktyka likarya pry postanovtci diagnozu sepsysu. Khirurgiya dytyachoho viku.2009; 3: 82-86.

[47] Kovalyova OM. Analiz zvyazku I/D polimorfizmu gena angiotenzyn-peretvoryuyuchoho fermentu z rozvytkom sepsysu ta pnevmonii u peredchasno narodzhenyh ditey. Klinichna ta eksperementalna patologiya.2012; 4: 77-81.
[48] Kozlov VK. Sepsis: immunopatogenez tyazholoho sepsisa. Klinichna imunologiya. Alergologiya. Infectologiya.2009; 1-2: 17-24.

[49] Kozlov VK. Sepsis: immunopatogenez tyazholoho sepsisa. Klinichna imunologiya. Alergologiya. Infectologiya.2009; 3: 6-13.

[50] Pypa LV, Murgina MM. Suchasni uyavlennya pro patogenez i diagnostyku gnyno-septychnyh staniv u ditey. Infektciyni hvoroby.2017; 2: 3240 .

[51] Mogylnyk AI. Syndrom systemnoho kapilyarnoho vytoku ta metody yoho korektcii $\mathrm{V}$ intensyvniy terapii krytychnyh staniv. Klinichna khirurhiya.2018; 85 (4): 57-61. DOI: https://doi.org/10.26779/ 2522-1396.2018.04.57

[52] Susak YaM, Zub OI, Lobanova OM, ta inshi. Vplyv unistatynu na metabolizm tcyrculyuyuchyh leykotcytiv ta syrovotkovy riven negistonovyh bilkiv 1 vysocomobilnoi grupy u hvoryh na gostry pankreatyt. Klinichna khirurgiya.2018; 85 (10): 21-25. DOI: https://doi.org/10.26779/ 2522-1396.2018.10.21

[53] Maltceva LA, Bazelenko DV. Patogenez tyazhyoloho sepsisa i septicheskoho shoka: analiz sovremennyh kotceptcy. Medicyna neolozhnyh sostoyany.2015; 7 (70): 35-40.

[54] Mamedov AA, Alieva EA, Gasanov NM, i drugie. Vzaimosvyaz markerov endotelialnoy disfunktcyi pri gnoynom holangite u bolnyh s hronicheskim hepatitom $\mathrm{i}$ bez hronicheskoho hepatita na fone obturatcyonnoy zheltuhi. Klinichna khirurhiya.2018; 85 (12): 9-12.

[55] Pypa LV, Murgina MM. Porivnyalny analiz informatyvnosti suchasnyh biomarkeriv sepsysu u ditey. Mizhnarodny zhurnal pediatrii, akusherstva ta hinekolohii.2017; 11 (1): 14-23.

[56] Osoba IA. Osoblyvosti funktcionuvannya systemy antyoxudantnoho zahystu organizmu. Ry- 
bohospodarska nauka Ukrainy.2009; 1: 133139.

[57] Ankyn NL, Petryk TM, Potochylova VV. Rol mikrobiolohicheskoho obsledovaniya $\mathrm{v}$ diagnostike i lechenii periproteaznoy infektcyi. Klinichna khirurhiya.2019; 86 (3): 52-55.

[58] Kryvoruchko IA, Boyko VV, Lavrenteva OYu, ta inshi. Zminy oxudantno-antyoxudantnoho homeostazu ta okremyh tcytokiniv u hvoryh z blastomatoznoyu zhovtyanytceyu riznoi tyazhkosti. Klinichna khirurhuya.2019; 86 (1): 3-9.

[59] Kryvoruchko IA, Boyko VV, Ivanova $\mathrm{YuV}$, ta inshi. Sepsys-3: onovleni vyznachennya, potentciyni problemy ta podalshi praktychni kroky. Klinichna khirurhiya.2019; 86 (6): 60-72. DOI: https://doi.org/10. $26779 / 2522-1396.2019 .06 .60$

[60] Takagi.Y, Masamune A, Kume A, at al. Microsatellite polymorphism in intron 2 of humen Toll-like receptor 2 gene is associated with susceptibility to acute pacreatitis in Japan. Hum. Immunol. 2009; 70 (3): 200-202. DOI: https://doi.org/10.1016/j. humimm.2009.01.006 [PMid:19280717]

[61] Saidov MZ. Ekspresiya TLR v nosovyh polipah I na kletkah perifericheskoy krovi u bolnyh polipoznyh rinosinusitov. Immunolohiya.2008; 5: 272-278.

[62] Kutcenko LA, Kaydyshev IP. Mesto tceruloplazmina sredi belkov ostroy fazy kak markera systemnoho vospaleniya. Laboratornoye delo.2011; 3 (57): 59-68.

[63] Korsunov VA. Laktatatcydoz pry sepsysi u ditey. Scientific Journal $\ll$ ScienceRise $\gg .2015$; 2/4 (7): 39-45.

[64] Purcarea A, Bourgarit A, Sovaila A, at al. Brief report: Serial capillary lactate measurement predict the evolution of early sepsis.J Med Life.2016; 9 (1): 74- 78.
[65] Skalny A. Himicheskie elementy v fiziolohii i ekolohii cheloveka. Moskva: Mir; 2004.215s.

[66] Lezhenko GO, Pashkova OE. Infektcii, vyklykani palychkoyu synyo-zelenoho hnoyu, stara problema, shcho potrebuye novyh rishen. Dytyachy likar. 2013; 5 (26): 9-18.

[67] Kryvoruchko IA, Usenko OYu, Andreeshchev SA. Khirurhichne likuvannya hvoryh $\mathrm{z}$ pryvodu abdominalnoho sepsysu. Klinichna hirurhiya.2014; 8: 34-38.

[68] Emmanuel S, Franziska M, Julia S, et al. Flow Cytometry-Based Quantification of Neutrophil Extracellular Traps Shows an Association with Hypercoagulation in Septic Shock and Hypocoagulation in Postsurgical Systemic Inflammation- A Proof-of-Concept Study. J.Clin.Med.2020; 9: 174 DOI: https : //doi.org/10.3390/jcm9010174 [PMid:31936385 PMCid:PMC7019434]

[69] Abrams ST, Mbchb BM, Alhamdi Y, Alsabani $\mathrm{M}$, et al. Novel Assay for Neutrophil Extracellular Traps (NETs) Formation Independently Predicts Disseminated Intravascular Coagulation and Mortality in Critically Ill Patients Correspondence.2019; 143. DOI: https://doi.org/10.1164/ rccm.201811-21110C [PMid:31162936 PMCid:PMC6812439]

[70] Yang S, Qi H, Kan K, Chen J, Xie H, Guo $X$, Zhang L. Neutrophil Extracellular Traps Promote Hypercoagulability in Patients With Sepsis. SHOCK. 2017; 47: 132- 139. DOI: https://doi.org/10.1097/SHK. 0000000000000741 [PMid:27617671]

[71] Aydemir TB, Chang SM, Guthrie GJ, et al. Zinc transporter ZIP14 functions in hepatic zinc, iron and glucose homeostasis during the innate immune response (endotoxemia). PLoS One. 2012; 7: e48679. DOI: https://doi.org/ 10.1371 / journal.pone.0048679 [PMid:23110240 PMCid:PMC3480510] 
[72] Wessels I, Cousins RJ. Zinc dyshomeostasis during polymicrobial sepsis in mice involves zinc transporter Zip14 and can be overcome by zinc supplementation. Am J Physiol Gastrointest Liver Physiol. 2015; 309: 768- G778. DOI: https://doi.org/10.1152/ a jpgi.00179.2015 [PMid:26272258 PMCid:PMC4628964]

[73] Xie J, Wang H, Kang Y, et al. The Epidemiology of Sepsis in Chinese ICUs: A National Cross-Sectional Survey. Crit.Care Med. 2019; 5:

[74] Dickson K, Liu S, Zhou J, et al. Selective sensitivity of the gut microbiome to iron chelators in polybacterial abdominal sepsis. Med Hypotheses. 2018 Nov; 120: 6871. DOI: https://doi.org/10.1016/ j.mehy.2018.08.018 [PMid:30220344]

[75] Ozdemir S, Toplan S, Tanriverdi G, Sunamak O.The effects of $\beta$-glucan on iron levels and lipid peroxidation in intra-abdominal sepsis in rats.Gen Physiol Biophys. 2011; 30 (2): 13844. DOI: https://doi.org/10.4149/ gpb_2011_02_138 [PMid:21613668]

[76] Sekovanić A, Jurasović J, Piasek M1, et al. Metallothionein 2A gene polymorphism and trace elements in mother-newborn pairs in the Croatian population. J. Trace Elem Med Biol. 2018 Jan; 45: 163-170 DOI: https://doi.org/10.1016/j. jtemb.2017.10.011 [PMid:29173474]

Received: 2020-01-20

Revised: 2020-04-09

Accepted: 2020-04-13 